Portland State University

PDXScholar

\title{
Assessing the Potential Contribution of Vacant Land to Urban Vegetable Production and Consumption in Oakland, California
}

\author{
Nathan McClintock \\ Portland State University, n.mcclintock@pdx.edu \\ Jenny Cooper \\ University of California - Berkeley \\ Snehee Khandeshi \\ University of California - Berkeley
}

Follow this and additional works at: https://pdxscholar.library.pdx.edu/usp_fac

Part of the Public Policy Commons, Urban Studies Commons, and the Urban Studies and Planning Commons

Let us know how access to this document benefits you.

\section{Citation Details}

McClintock, Nathan; Cooper, Jenny; and Khandeshi, Snehee, "Assessing the Potential Contribution of Vacant Land to Urban Vegetable Production and Consumption in Oakland, California" (2013). Urban Studies and Planning Faculty Publications and Presentations. 92.

https://pdxscholar.library.pdx.edu/usp_fac/92

This Post-Print is brought to you for free and open access. It has been accepted for inclusion in Urban Studies and Planning Faculty Publications and Presentations by an authorized administrator of PDXScholar. Please contact us if we can make this document more accessible: pdxscholar@pdx.edu. 
Assessing the potential contribution of vacant land to urban vegetable production and consumption in Oakland, California

\author{
Nathan McCLINTOCK* \\ Jenny COOPER \\ Snehee KHANDESHI \\ Department of Geography, University of California, Berkeley, CA 94720-4740, USA \\ * Corresponding author at: Toulan School of Urban Studies and Planning, Portland State \\ University, Portland, OR 97207-0751, USA. Tel.: +1 503725 4064; fax: +1 5037258770 \\ Email address: n.mcclintock@pdx.edu (N. McClintock)
}




\section{Highlights}

- We identify more than 335 ha of vacant public land with potential urban agricultural value.

- The contribution of vacant land to vegetable requirements depends largely on management practices.

- Committing 40 ha to vegetable production could contribute more than $5 \%$ of current needs. 


\section{Introduction}

2

11 neighborhoods with limited access to healthy food while offering opportunities for employment,

12 education, and recreation (Hodgson et al., 2011; Hou, Johnson, \& Lawson, 2009; Redwood,

14 As planners, public health officials, and community groups alike articulate the linkages

15 between food systems, health, and the built environment (Corburn, 2009; Muller, Tagtow,

16 Roberts, \& MacDougall, 2009; Pothukuchi, 2009), locating possible sites for urban agriculture

17 has become a priority. Over the past few years, researchers have conducted inventories of vacant

18 land with agricultural potential in Portland (Balmer et al., 2005), Vancouver (Kaethler, 2006),

19 Seattle (Horst, 2008), Cleveland (Grewal \& Grewal, 2012; Taggart, Chaney, \& Meaney, 2009),

20 Detroit (Colasanti \& Hamm, 2010), Toronto (MacRae et al., 2010), Chicago (Taylor \& Lovell,

21 2012), and New York (Ackerman, 2012). Only some of these inventories, however, estimate the

22 potential productivity of the identified land or its ability to meet consumer demands for fresh

23 fruits and vegetables. 
To address health disparities in Oakland, California, food justice organizations interested

25 in ramping up urban agriculture have eyed the city's numerous vacant lots. Until the research

26 presented in this article was conducted, the scale of potential production was unknown, both in

27 terms of the spatial extent of vacant land and its potential contribution to the food system. In this

28 paper we detail the development, implementation, and results of a geographic information

29 system (GIS)-based inventory of Oakland's vacant and underutilized public and private land

30 conducted in collaboration with one such food justice initiative, the HOPE Collaborative

31 (hereafter, HOPE). The goals of the inventory, entitled Cultivating the Commons (CTC), were to:

32 1) identify potential sites for urban agriculture on vacant and underutilized public land in

33 Oakland; 2) quantify the spatial extent this land; and 3) estimate its potential contribution to

34 Oakland's food system.

35 In this article, we present a description of the study site and context before presenting the

36 methods and results of both the CTC inventory and our more recent calculations of urban

37 agriculture's potential contribution to Oakland's vegetable consumption. We conclude by

38 discussing potential limitations of the analysis and possible ways to hone the methodology.

$40 \quad 2$. Study Site and Context

\section{2.1. Biophysical landscape}

This study was conducted in the city of Oakland, California (WGS84 37.804444, -

43 122.270833). Three primary topographic zones define the city’s physical geography: flatlands,

44 foothills, and hills. The flatlands are low-lying areas largely comprised of fill (e.g., dredged

45 sediment, construction debris, quarried rocks), adjacent to the San Francisco Bay to the city's

46 west and Alameda Estuary and San Leandro Bay to the south (see Figure 1). The foothills are 
47 formed on a gentle fan of alluvium spreading downwards from the Oakland hills, a series of

48 undulating, parallel ridges thrust upwards along the Hayward and Moraga faults and which run

49 along the city's eastern portion along a northwest-southeast axis (Sloan, 2006). Soils in the

50 flatlands are a mix of urban land (highly mixed, heterogeneous fill) and complexes of urban land

51 and endogenous soils derived from sedimentary, alluvial parent material, while the complexes in

52 the hills are dominated by a number of excessively drained loams weathered from uplifted

53 conglomerate and ultrabasic metamorphic rock (Welch, 1981). The climate is Mediterranean

54 with wet winters and dry summers with morning fog. Average annual precipitation is 22.9 in

$55(582.7 \mathrm{~mm})$, with $89 \%$ of the total rainfall occurring between November and April. September is

56 the hottest month with an average high temperature of $80.6^{\circ} \mathrm{F}\left(27^{\circ} \mathrm{C}\right)$; January is the coldest

57 month, with an average high of $58.1^{\circ} \mathrm{F}\left(14.5^{\circ} \mathrm{C}\right)$ (NOAA, 2004). Native vegetation includes oak

58 (Quercus sp.) woodland, coastal shrub, and coastal terrace prairie, with large redwood (Sequoia

59 sempervirens) stands in the drainages (Beidleman \& Kozloff, 2003).

60 [FIGURE 1 ABOUT HERE]

\section{2.2. Social landscape}

63 Oakland (pop. 391,000) is one of three core cities in the San Francisco Bay Area, a major

64 American metropolitan region populated by 7.2 million people and comprised of nine counties

65 and 101 municipalities (U.S. Census Bureau, 2010). Oakland's downtown central business

66 district is located immediately west of Lake Merritt, the physical landmark demarcating East

67 Oakland from the rest of the city. Two freeways roughly delimit the flatlands from the hills: CA-

6824 along the north-south axis west of downtown, and I-580 along the northwest-southeast axis

69 south of the Oakland hills and foothills (see Figure 1). 
From its founding in the early 1850 s, the city grew eastwards from West Oakland and

71 downtown. The terminus of the trans-continental railroad in West Oakland led to the city's rapid

72 growth beginning in the late $19^{\text {th }}$-century, followed by major shipbuilding, automobile

73 manufacture, and food processing during the First World War. For most of the $20^{\text {th }}$ century,

74 industry, commercial transportation, and warehousing were concentrated in the flatlands around

75 the Port of Oakland in West Oakland and along the Alameda Estuary. The remainder of the

76 flatlands and hills developed as residential neighborhoods (U.S. Census Bureau, 2010; Walker,

77 2001).

78 Census data reveal a disproportionate concentration of poverty in the flatlands of North,

79 West, and East Oakland, affecting a population that is majority African American, Southeast

80 Asian, and Latino. Most of Oakland's white population lives in the more affluent foothills and

81 hills neighborhoods (U.S. Census Bureau, 2010). The spatial inequities of the socioeconomic

82 landscape are largely due to the historical demarcation of areas where particular ethnic groups

83 were allowed to live as well as where investment capital flowed. During the first half of the $20^{\text {th }}$

84 century, "redlining" by insurance companies prevented investment in "high risk" low-income

85 areas, while racial covenants prevented people of color from living in white neighborhoods.

86 During the 1960s and 1970s, freeway construction bifurcated the city while deindustrialization

87 prompted the outflow of commercial capital and a declining tax base (McClintock, 2011; Self,

88 2003; Walker, 2001).

89 This bifurcation of the socioeconomic landscape into hills and flatlands has also defined

90 access to healthy and affordable food in Oakland. In Oakland, $20 \%$ of families live below the

91 federal poverty line. Approximately one-third of Alameda County's residents are food insecure

92 and $87 \%$ of Oakland school children receive free or reduced-price lunch (ACPHD, 2008; OFPC, 
93 2010). Areas with limited access to healthy food—so-called "food deserts"- are located in the

94 flatlands and are closely tied to its history of disinvestment (HOPE Collaborative, 2009;

95 McClintock, 2011). Over the last decade, several food justice organizations have attempted to

96 address inequitable access to healthy food through a variety of programs and policy

97 recommendations. Urban agriculture has been central to these efforts and has begun to figure

98 prominently in food systems, public health, and land use planning discussions in Oakland

99 (McClintock, Wooten, \& Brown, 2012).

100

\section{2.3. Study Context}

102 Oakland's vibrant food justice movement and a growing body of community-based

103 participatory research in public health (Israel, Eng, Schulz, \& Parker, 2005; Minkler \&

104 Wallerstein, 2003) and environmental justice (Corburn, 2005; Metzger \& Lendvay, 2006;

105 Petersen, Minkler, Vasquez, \& Baden, 2006) inspired this research. Developed iteratively with

106 community stakeholders, the project took shape within the following context. In 2006 the

107 Oakland City Council embraced a goal of sourcing $30 \%$ of its food locally, and passed

108 Resolution No. 79680 to support a food system assessment for the city. The resulting Oakland

109 Food System Assessment (OFSA) evaluated the existing avenues of food distribution and

110 consumption in Oakland, including food production within a $200 \mathrm{mi}(321.9 \mathrm{~km})$ radius from the

111 city (Unger \& Wooten, 2006). While the vast majority of food consumed in Oakland comes

112 from outside of this area, local food systems advocates have underscored the importance of food

113 production within the city itself in order to promote education, reduce the distance between

114 production and consumption, enhance green space, and create green job opportunities (Hodgson

115 et al., 2011; OFPC, 2010). While urban agriculture in Oakland is widespread, the contribution of 
116 existing gardens to the city's total consumption of vegetables is unknown and difficult to

117 quantify. There are currently more than 100 school gardens in Oakland, 10 community gardens

118 managed by the Office of Parks and Recreation (OPR), and dozens managed by non-profit

119 organizations (Farfan-Ramirez, Olivera, Pascoe, \& Safinya-Davies, 2010; OFPC, 2010; Unger

$120 \&$ Wooten, 2006). No data on residential gardening exists for Oakland, but national data reveal

121 that almost $40 \%$ of Americans grow vegetables in their yards (Marks, 2008).

122 Because the potential contribution of urban agriculture was also unknown, the OFSA's

123 first recommendation regarding local food production was to: "Initiate an inventory of land that

124 is potentially suitable for urban agricultural production. Such an inventory would ideally include

125 both suitable public land (e.g., rights-of-way, easements, parks) and private land (e.g., rooftops,

126 vacant lots, backyard gardens)" (Unger \& Wooten, 2006, p. 105). A 2008 meta-analysis of

127 existing data on production, distribution, consumption, and waste recovery in Oakland's food

128 system reiterated the need for a land inventory in order to calculate the city's agricultural

129 potential, noting that "it would be useful to have a better sense of production capacity in order to

130 understand land acquisition and programming needs/costs" (Wooten, 2008, p. 19).

131 Between October 2007 and June 2009, this paper's lead author (N. McClintock) was

132 involved with HOPE as a participant observer. During this time, HOPE members conducted an

133 assessment of the food system and built environment in six low-income "micro-zones" in the

134 flatlands. The assessment included interviews, inventories, community listening sessions, and

135 charrettes that involved mapping and visioning a "healthier, greener Oakland" (Herrera, Khanna,

136 \& Davis, 2009; HOPE Collaborative, 2009). Participants repeatedly expressed the need to know

137 the potential for urban agriculture to expand in Oakland. Over the course of 2008, discussions

138 with HOPE members helped to define a specific research question: To what extent could urban 
agriculture on Oakland's vacant and underutilized vacant land contribute to the city's food

140 system? Key sub-questions included: Where is there available land? Who owns it? How much is

141 there? How much produce could be grown on it?

142 In early 2009, HOPE members collectively prioritized the need to move forward with

143 such an assessment as a crucial first step toward the development of a robust food system for

144 low-income flatlands neighborhoods and funded a research assistant (J. Cooper) to help complete

145 the inventory. McClintock and Cooper completed the majority of GIS analysis and mapping

146 between January and June 2009 and released a final report (McClintock \& Cooper, 2009) in

147 October 2009, with hopes that the inventory might help non-profit organizations and city

148 officials identify potential urban agriculture sites and inform food policy decisions.

149 Over the course of the project we worked collaboratively with HOPE members, city

150 officials, and urban agriculture organizations, establishing a community advisory committee

151 made up of members from these groups to brainstorm criteria for selection of potential sites and

152 provide feedback on what information would be useful in the finished report. Advisory

153 committee members also provided feedback on several drafts of the report before its release. The

154 process of defining the parameters of the research was iterative, a defining characteristic of

155 collaborative or participatory research (Israel et al., 2005; Minkler \& Wallerstein, 2003).

156 Moreover, the project itself was iterative, and continued even after the report's release. Extensive

157 ground-truthing of sites was conducted throughout 2010. In Fall 2010, McClintock conducted a

158 finer-grained slope analysis and a research assistant (S. Khandeshi) analyzed a data layer of

159 privately owned vacant land. Building on methods used in assessments of vacant land in Detroit

160 (Colasanti \& Hamm, 2010) and Toronto (MacRae et al., 2010), McClintock then calculated the

161 potential contribution of inventoried vacant land to Oakland's estimated current and 
162 recommended vegetable consumption. The methods and results of the entire project- the CTC

163 public land inventory, the private land inventory, and productivity calculations - are reported

164 here in detail.

165

166 3. Methods

167 3.1. Vacant land inventory

168 Following the lead of early vacant land inventories conducted in Portland (Balmer et al.,

169 2005), Vancouver (Kaethler, 2006), and Seattle (Horst, 2008), our goal was to locate vacant

170 parcels that could potentially serve as sites of food production. Upon initial examination, we

171 realized that the amount of actual vacant public land (e.g., land with no existing use, such as a

172 park or lawn or playing field) in Oakland was limited. We therefore chose to broaden the scope

173 of our investigation to include any underutilized public land that could potentially be used for

174 crop production, with the understanding that actual site selection would ultimately depend on

175 additional criteria and community input.

176 [FIGURES 2a and 2b ABOUT HERE]

177 We used ArcGIS 9.3 software to identify, delineate, and catalog areas where crops could

178 potentially be grown, as well as to calculate area, slope, and aspect of the sites. The land

179 included in the inventory belongs to public agencies spanning multiple administrative levels,

180 from municipal to federal (see Table 1). We first used Alameda County Tax Assessor's parcel

181 data obtained from the City of Oakland's GIS database to identify the 2,551 publicly owned

182 parcels totaling 10,013 ac $(4,052.1$ ha) of land, or nearly a third of Oakland's total area of 35,703

183 ac (14,448.5 ha). Zoning and General Plan land use classifications were joined to each site.

184 [TABLE 1 ABOUT HERE] 
186 Program (NAIP) 1-m satellite imagery (USDA, 2005). Systematically following a 1-km grid

187 overlay, we used visual interpretation to select parcels containing potentially arable land,

188 including parcels that appeared vacant or that contained lawns, fields, and other open spaces

189 within a park or adjacent to a government facility (see Figures $2 \mathrm{a}$ and $2 \mathrm{~b}$ ). We excluded fully

190 developed parcels and spaces with an apparent use, such as playing fields and parking lots, but in

191 a few cases included parking lots that appeared to have been abandoned, as such sites could be

192 used for food production in greenhouses or raised beds.

193 We clipped out buildings and developed areas such as roads, playing fields, and parking

194 lots and classified each parcel into one of four ground cover categories: soil/grass (less than $25 \%$

195 coverage by dense vegetation or hard surface); hard surface ( $>25 \%$ asphalt, concrete, or gravel,

196 and $<500 \mathrm{ft}^{2}$ of contiguous open soil/grass); mixed surface ( $>25 \%$ asphalt, concrete, or gravel,

197 but $>500 \mathrm{ft}^{2}$ of contiguous open soil/grass), or dense vegetation ( $>25 \%$ dense vegetation and

$198<500 \mathrm{ft}^{2}$ of contiguous open soil/grass). Dense vegetation parcels containing $<500 \mathrm{ft}^{2}$ of

199 contiguous open soil/grass were removed, while those containing $>500 \mathrm{ft}^{2}$ were modified by

200 clipping out the vegetation. Finally, any parcel with $<500 \mathrm{ft}^{2}\left(46.5 \mathrm{~m}^{2}\right)$ of open space was

201 removed from the final inventory.

202 The aggregated area that remained (which included soil/grass, hard surface, and mixed

203 surface) formed the total area classified as arable. To calculate slope at each site, we transformed

204 parcel polygons to a raster and calculated average slope for each $100 \mathrm{~m}^{2}$ raster square using a

205 digital elevation model (DEM). The raster was then reclassified into: slopes $<10 \%$; between 10

206 and 30\%; and $>30 \%$, a practical threshold slope for cultivation (while agriculture is practiced on

207 slopes greater than $30 \%$ in many parts of the world, terracing or other stabilization techniques are 
generally required). Using the slope raster and DEM, we also created an aspect raster, which we

209 then reclassified as "optimal" ( $<30 \%$ slope and W, SW, S, SE, or E aspect) or "less desirable"

210 (>30\% slope and NW, N, or NE aspect). Finally, we spatially joined water meters, schools, and

211 bus stops to the inventory layer, and queried all sites within $10 \mathrm{ft}$ ( $3.05 \mathrm{~m}$ ) of a water meter, 0.25

$212 \mathrm{mi}(0.40 \mathrm{~km})$ of a school, and $/$ or $0.25 \mathrm{mi}(0.40 \mathrm{~km})$ of a bus stop, attributes that were presented

213 in the final database and report.

214 To account for limitations posed by visual interpretation of the NAIP imagery, we cross-

215 checked all sites with more recent Google Maps imagery and visited a geographically

216 representative sample of sites to assess vegetation density and slope. We visited 50 of 495 total

217 sites (10\%) in 2009, and an additional 120 sites (24\%) in 2010 under the purview of a related soil

218 sampling project (McClintock, 2012). Overall, seven densely vegetated sites (4\% of total

219 ground-truthed sites) were removed from the inventory.

220 Using vacant parcels data obtained from the UC Berkeley Department of City and

221 Regional Planning in Fall 2010, we followed roughly the same GIS protocol to calculate the

222 amount of potentially arable privately owned vacant land. This time we used ArcGIS 10 and a

223 current Bing Maps base layer (rather than NAIP imagery) to visually interpret the 4,249 vacant

224 parcels. Given the extensive labor required, we modified the selection criteria, whereby parcels

225 containing $>25 \%$ dense vegetation were removed from the inventory. Similarly, parcels

226 containing $>25 \%$ infrastructure (such as outbuildings or pavement) or with a clear existing use

227 (such as parking or junk storage) were removed. Due to the variation in selection criteria

228 between public and private parcels, we have chosen to report the results separately.

229

\subsection{Calculating consumption}


232 and age cohorts) from the 2010 US Census, then aggregated cohorts into larger groups based on

233 USDA recommendations for vegetable intake. Recommended consumption for all cohorts was

234 then aggregated into an overall citywide demand (see Table 2). Both the Detroit (Colasanti \&

235 Hamm, 2010) and Toronto (MacRae et al., 2010) studies, however, assessed the potential for

236 vacant land to contribute to actual consumption rather than recommended consumption.

237 Following the Detroit study, we obtained consumption data from the USDA ERS Loss-Adjusted

238 Food Availability Database (USDA, 2010) which calculates average national per capita fresh

239 vegetable consumption from aggregate production, adjusting for losses between production and

240 consumption. Using the national per capita consumption for each fresh vegetable crop (see

241 Appendix A), we extrapolated current and recommended Oakland consumption based on the

242 population data presented in Table 2.

\section{3 [TABLE 2 ABOUT HERE]}

244 When calculating potential productivity of vacant land, it is important to factor in both

245 the geographic adaptability of a particular crop to the local agroecosystem and its seasonality.

246 Following the Detroit study, we calculated the potential local/seasonal share of current and

247 recommended consumption, divided the number of months that a particular crop can be

248 harvested in Oakland by 12 months, then multiplied the coefficient by estimated current and

249 recommended consumption levels for each crop (see Appendix A). Three of the USDA database

250 crops - lima beans, okra, sweet corn, and sweet potatoes - do not grow well in Oakland,

251 requiring warmer and sunnier conditions (sweet corn, for example, rarely produces large ears

252 during the Bay Area foggy summers). They were therefore excluded from the local/seasonal

253 productivity calculations. 


\section{3.3. Calculating productivity}

256 No yield data was available from actual urban gardens in Oakland. The Detroit study

257 used three different production scenarios to estimate the amount necessary to meet consumer

258 demands: high-productivity biointensive, low-productivity biointensive, and commercial.

259 Following this logic, we averaged California statewide yield data from 1998 to 2008 for each of

260 the vegetable crops listed in the USDA database as well as low and medium yields using

261 biointensive methods calculated in Northern California (Jeavons, 2002). Vegetable yields under

262 conventional management average 13.2 tons per acre $(29.6 \mathrm{Mg} / \mathrm{ha})$. Low biointensive yields,

263 which assume a beginning gardener, are slightly higher at 15.4 tons per acre $(34.5 \mathrm{Mg} / \mathrm{ha})$ while

264 medium biointensive yield averages are twice as high (30.8 tons per acre or $69.0 \mathrm{Mg} / \mathrm{ha}$ ) (see

265 Appendix 2). Unlike the Detroit researchers, we used medium biointensive yields for each crop

266 rather than high yields (which many gardeners argue are unrealistic). Finally, we interviewed

267 three organic farmers operating intensive commercial and/or educational operations in other

268 urban or peri-urban areas with Mediterranean growing climatic conditions. Farms were located

269 in Davis and Santa Cruz, California (both approximately $110 \mathrm{~km}$ from Oakland, east and south,

270 respectively) and Eugene, Oregon ( $830 \mathrm{~km}$ north of Oakland). They verified that our selected

271 range of yields was realistic, depending on crop choice and management.

272 While the Toronto study calculated productivity based on Statistics Canada yield data

273 unadjusted for losses, we followed the Detroit study's method of using state and federal data to

274 calculate yields and farm to consumer losses at different stages in the commodity chain. The

275 USDA database reports average estimated post-harvest losses at various stages between farm and

276 table: farm to retail, retail to consumer, and inedible share (i.e., the portion of the raw vegetable, 
277 such as stems, that are not actually consumed). These farm-to-table losses are needed to calculate

278 the overall production required to meet both estimated current consumption and recommended

279 consumption levels. Appendix 2 lists these losses for each crop of interest. On average, there is a

$28063 \%$ loss in weight from farm to table, but these vary considerably by crop.

\section{3.4. Calculating potential contribution of vacant land}

To estimate the contribution of vegetable production on Oakland's vacant land to the

284 city's estimated current and recommended vegetable consumption, we calculated production

285 under four different land use scenarios. The first two scenarios use total areas calculated during

286 the GIS inventory. A highly unlikely Scenario 1 assumes that all available land with a slope

$287<30 \%$ would be used for vegetable production, while Scenario 2 uses only "optimal" acres (i.e.,

288 the Scenario 1 total excluding all NW, N, and NE-facing land). Scenarios 3 and 4 represent two

289 more realistic scenarios, where specific (but arbitrary) amounts of land would be dedicated to

290 urban agriculture, for example, by an act of City Council or OPR. Scenario 3 is based on a

291 "High" land use of 500 ac (202.3 ha), while Scenario 4 is perhaps the most realistic, a "Low"

292 land use of $100 \mathrm{ac}(40.5 \mathrm{ha})$. In all Scenarios, we assumed that $75 \%$ of a site's arable total land

293 area would be used for crop production, with the remaining $25 \%$ taken up by infrastructure and

294 non-productive space (between-row aisles, turning lanes at the end of the rows, etc). We then

295 calculated the potential contribution under three agricultural management practices:

296 conventional, biointensive (low), and biointensive (medium). For the sake of developing a "back

297 of the envelope" metric for other studies, we rounded down to a slightly more conservative

298 average yield for each of these management practices, using 10,15 , and 25 tons/ac $(22.4,33.6$, 
299 and $56.0 \mathrm{Mg} / \mathrm{ha}$ ), for conventional, bio-intensive (low), and bio-intensive (medium),

300 respectively.

301

302 4. Results

303 4.1. Consumption

304 Based on Oakland's 2010 population of 390,724, the recommended annual vegetable

305 consumption by city's population totals 90,766 tons ( $82,341.5 \mathrm{Mg}$ ) (Table 4). According to the

306 USDA Americans annually consume $97.9 \mathrm{lbs}(44.4 \mathrm{~kg})$ of fresh vegetables per capita. Assuming

307 that Oakland follows the same pattern, Oaklanders currently consume 19,126 tons $(17,350.8 \mathrm{Mg})$

308 of fresh vegetables, or only $21 \%$ of the recommended total.

309 We estimate that 28,884 tons $(26,203.1 \mathrm{Mg})$ are needed to meet estimated current

310 consumption levels, and 137,016 tons $(124,298.8 \mathrm{Mg})$ needed to meet recommended levels.

311 Considering the geographic adaptability and seasonality of crops, the overall possible local

312 contribution to production needs is slightly lower (see Table 3).

313 [TABLE 3 ABOUT HERE]

314

315 4.2. Public land

316 Overall, we identified roughly 1,200 ac (486.0 ha) of arable land on 495 aggregated sites

317 consisting of 756 individual tax parcels (see Figure 3). Slightly more than half (629 ac, or 254.5

318 ha) of land identified in the inventory is currently owned or managed by OPR. The sites are

319 distributed relatively evenly across the city, but the vast majority of arable public land is located

320 in East Oakland, with another large number of sites located in the West Oakland flatlands. While 
321 a significant amount of open space is located on public land in the Oakland hills, much of this

322 land is fragmented, located on slopes $>30 \%$, and inaccessible by road.

323 [FIGURE 3 ABOUT HERE]

324 More than one-third of the sites are small parcels $>0.25 \mathrm{ac}(0.1 \mathrm{ha})$, which, based on size

325 alone, would be best suited for community gardens. Another one-third of the sites are between

3260.25 and 1 ac ( 0.1 to $0.4 \mathrm{ha}$ ) and might be best used as community gardens or small market

327 gardens run by urban agriculture organizations. A final one-third of the sites are between 1 and 5

328 ac (0.4 to 2.0 ha) and could be developed as large market gardens or "mini-farms" run by urban

329 agriculture organizations or leased to individual commercial urban farmers. Finally, 45 sites are

$330>5 \mathrm{ac}(2.0 \mathrm{ha})$ and could be used as urban farms managed by urban agriculture organizations or

331 leased to commercial farmers for large-scale urban production.

332 Most of the identified land (1,078 ac, or $436.3 \mathrm{ha})$ has soil or grass as ground cover,

333 while 26 parcels totaling 30 ac (12.1 ha) are covered with an impermeable ground cover such as

334 gravel, concrete, or asphalt. Such sites would be suitable for greenhouses or raised beds (or used

335 for compost processing, distribution centers, and/or storage). The land is almost evenly divided

336 between level ( $<10 \%$ slope), sloping (10 to 30\%), and steep land ( $>30 \%)$. More than a third of

337 the land (nearly 410 ac or 165.9 ha) is level (see Figure 3). Parcels with the most level terrain

338 would be optimal for community gardens. Aspect, or directional exposure to the sun, is another

339 key consideration when considering crop production, particularly on moderate to steep slopes.

340 Overall, roughly $12 \%$ of the total area faced NW, N, or NE. Our "optimal site" calculation

341 yielded a total of 730 ac (295.4 ha), or $62 \%$ of the total area (see Table 4$)$.

342 [TABLE 4 ABOUT HERE] 
344 vegetable consumption in Oakland under three different production systems. Under ideal

345 growing practices, even the Low land use scenario, which commits 100 ac (40.5 ha) to vegetable

346 production, could yield more than $5 \%$ of the city's estimated vegetable consumption, while the

347 High use scenario which commits 500 ac (202.3 ha), could produce roughly a third of the

348 estimated current consumption needs. More modest yields under conventional management

349 would result in 2.9 and $14.5 \%$ under the Low and High land use scenarios, respectively. Because

350 recommended consumption is so much higher than current consumption, the vacant land's

351 potential to meet these recommendations is lower. The Low land use scenario would contribute

352 as little as 0.6 to $1.5 \%$ to the city's food recommended consumption needs, while the High land

353 use scenario could deliver as much as $7.7 \%$, depending on management practices.

354 [TABLE 5 ABOUT HERE]

355

\subsection{Private land}

357 Overall, we identified 3,008 privately owned vacant parcels, totaling 864 ac (349.6 ha)

358 (see Figure 3). The vast majority of this land (2,484 parcels totaling 289 ac, or 117.0 ha) consists

359 of lots $<0.25 \mathrm{ac}(0.1 \mathrm{ha})$. Fifteen large parcels $>5 \mathrm{ac}(2.0 \mathrm{ha})$ account for roughly a third of the

360 land (see Table 6). A slope analysis reveals that only $40 \%$, or 337 ac (136.4 ha) of the overall

361 area is located on slopes $<30 \%$. Many of the largest parcels are located on steep slopes in the

362 Oakland hills, likely the reason that they have not been developed.

363 [TABLE 6 ABOUT HERE]

364 Using the methods described above to calculate potential contribution of vacant land to

365 Oakland's vegetable consumption, private vacant could contribute an additional 3,370 tons 
$366(3,057.2 \mathrm{Mg})$ of vegetables under conventional farming practices, equaling 2.1 of Oakland's

367 current consumption or $9.8 \%$ of recommended consumption. Low-yield biointensive could

368 produce 5,055 tons $(4,585.8 \mathrm{Mg}), 14.7 \%$ of current consumption or $3.1 \%$ of recommended

369 consumption. Medium-yield biointensive could produce 8,425 tons $(7,463 \mathrm{Mg}), 24.5 \%$ of the

370 city's current consumption needs or $5.2 \%$ of recommended needs.

372 5. Discussion

373 5.1. Strengths of the study

374 This study identifies potential sites of production in Oakland and provides a preliminary

375 assessment of the capacity of this vacant land to contribute to the city's vegetable consumption.

376 Moreover, the analysis also reveals that a majority of arable sites are located in the flatlands,

377 where urban agriculture advocates are most active and the need for healthy produce the greatest.

378 Clearly, urban agriculture should not supplant all other uses of urban green space; public

379 open spaces must serve multiple purposes. The spectrum of land use scenarios therefore ranges

380 from the improbable Scenario 1 (where all land would be used) to the potentially possible

381 Scenario 4 where only 100 ac (14\% of the total optimal vacant land) would be devoted to urban

382 food production. Even under this scenario and the most conservative yield estimate, as much as

$3833 \%$ of the city's current consumption needs could be met. This contribution may seem

384 insignificant when weighing costs and benefits on production alone, but when considering urban

385 agriculture as only one (albeit spatially disparate) node in a network of local and regional

386 production, $3 \%$ is considerable, especially in a built environment as dense as the Bay Area.

387 Similar to our findings, vacant land in New York City could contribute to $2 \%$ of the city's

388 vegetable consumption under conventional methods (Ackerman, 2012), whereas in Detroit, 
where vacant public land alone totals 4,848 ac (1,961.9 ha) and the population shrinking, found

390 that one-third of current consumption levels could be met by farming vacant lots (Colasanti \&

391 Hamm, 2010), while Cleveland's 3,413 ac (1,381.1 ha) of vacant lots could contribute 22 to $48 \%$

392 to the city's produce (Grewal \& Grewal, 2012).

393 Beyond providing Oakland urban agriculture practitioners and policy makers with data,

394 this study helped to foster collaboration between researchers and the public. The project was

395 initially inspired by a broad range of stakeholders, many of whom also contributed to the land

396 inventory in an advisory capacity. Such integration of community participation is common in

397 environmental justice research and policy advocacy (Costa et al., 2002; Metzger \& Lendvay,

398 2006; Petersen et al., 2006), reflecting the broader collaborative turn in planning (Innes \&

399 Booher, 2010). It also gives primacy to the co-production of science for healthy city planning,

400 what Corburn (2009, p. 11) describes as a "polycentric, interactive, and multipartite sharing of

401 information" bringing together researchers, government agencies, and lay publics. On a more

402 immediate level, as Mendes et al. (2008) concluded in their comparative study of the Portland

403 and Vancouver land inventories, the success of moving from land inventory to successful

404 implementation of urban agriculture projects relies on the successful integration of stakeholders

405 into the inventory and planning process. Indeed, the preliminary GIS inventory of public land

406 that emerged from this project has played a role in ongoing efforts by city officials in Oakland to

407 update urban agriculture zoning (McClintock et al., 2012).

408 Furthermore, this study has both informed and built on other efforts to assess urban

409 agriculture's potential on vacant and underutilized land in North American cities. The original

410 CTC report provided methodological insights for several inventories that were conducted in

411 other cities (Ackerman, 2012; Colasanti \& Hamm, 2010; MacRae et al., 2010; Taggart et al., 
412 2009; Taylor \& Lovell, 2012). Two of these studies, in turn, helped us refine our own

413 consumption and productivity calculations.

415 5.2. Limitations to the methodology

416 This project solely sought to provide a rough, "back of the envelope" estimate of urban

417 agriculture's potential contribution to the food system. While the inventory was comprehensive, 418 there are several limitations worth noting:

\subsubsection{Data availability}

A primary limitation was the availability and currency of geospatial data. Even though

422 the tax assessor data file was updated quarterly, there was a lag time before shape files were

423 updated to reflect the tax assessor data. Because of the dynamic nature of development plans and

424 real estate transfers, each site would ideally be crosschecked with managing agencies and the

425 online tax assessor database; time and labor constraints prevented us from doing so. As outside

426 researchers without access to the tax assessor database, it was only possible to provide this

427 "snapshot" of vacant land at the time that the inventory was completed. A searchable Web GIS

428 version of the inventory, ideally linked to the existing tax assessor database and updated

429 immediately as sites are sold or transferred, could make current information available to the 430 public in a more user-friendly fashion.

431 The currency of aerial imagery was also an obstacle. When the CTC inventory was

432 completed, only 2005 NAIP imagery was available, thus the visual record of land use was

433 already four years old. To account for this, we crosschecked all sites using Google Maps to see if

434 they had been developed in the interim. While we were able to then delete newly developed sites 
435 from the inventory, we were unable to account for slight changes in vegetation. New NAIP

436 imagery, flown in Summer 2009, was released after we had completed the majority of the GIS

437 analysis of the public land. The release of ArcGIS 10, which includes up to date Bing basemap

438 imagery, greatly expedited our analysis of private land. For analysts using Quantum GIS,

439 GRASS, or other open source software, NAIP imagery is a free alternative, but may have slightly

440 lower resolution than Bing or Google imagery.

441

\section{$442 \quad$ 5.2.2. Visual interpretation}

443 The study also revealed the limitations of visual interpretation. Even with 1-m resolution,

444 what appears to be arable in an aerial or satellite-photo may not hold up to ground-truthing. The

445 annual grasses of the Bay Area turn a golden brown color during the dry season, making it

446 difficult to distinguish them from bare dirt or concrete at some sites. While ground-truthing of

$44734 \%$ of the publicly owned sites confirmed that our estimates were $96 \%$ accurate, further

448 comprehensive assessment of sites should be conducted to determine if all of them are actually

449 viable for food production. Indeed, ground-truthing ultimately prompted us to hone the slope

450 analysis in 2010 to better identify slopes that might be too steep to farm.

451 Another major drawback of our approach was its labor intensiveness. Visual assessment

452 of each parcel was incredibly time consuming, and clipping out vegetation and buildings and

453 other reshaping of polygons added a significant level of precision to the project. The HOPE

454 mini-grant funded 140 hours of GIS work, but we easily spent twice this amount of time

455 inventorying the publicly owned land. The private land inventory was completed much more

456 quickly because the Bing base map allowed us to eliminate the extra step of cross checking each

457 site against Google Maps. The use of remote sensing software to process aerial imagery could 
458 certainly speed up the process, but would be complicated by shading from buildings and

459 differentiating dry vegetation from other surfaces. Using higher resolution imagery for the entire

460 city would also require significant data processing capabilities. Indeed, recent land inventories

461 using remote sensing have extrapolated their results from small sub-sections of the city (Nipen,

462 2009; Welty, 2010).

463

464 5.2.3. Estimating production and consumption

465 There are limitations to calculating vegetable consumption (and by extension, necessary

466 production) at the city- or neighborhood-scale. Interpolating consumption based on national

467 averages is clearly problematic, especially when the demographics of poverty, race, and

468 ethnicity—all of which factor into food consumption patterns — differ between the municipal and

469 national scale. Vegetable consumption is closely correlated to education and income, with

470 significant differences in consumption between races and/or ethnic groups (Casagrande, Wang,

471 Anderson, \& Gary, 2007). Given the socioeconomic disparity between the flatlands and hills,

472 consumption patterns are surely even different within Oakland (hence the activism that has

473 emerged to address these inequities). Considering that $22 \%$ of Oakland's population lives in

474 poverty relative to $15 \%$ nationally (U.S. Census Bureau, 2010), the quanity of vegetables

475 actually consumed is likely lower than aggregate USDA data suggests.

476 Furthermore, the USDA averages likely do not reflect Oakland's ethnic — and culinary—

477 diversity; the culinary traditions and diets of the city's large Asian and Latino populations (17\%

478 and $25 \%$ of the city's population, respectively, versus $5 \%$ and $16 \%$ of the US population) are

479 rich in many vegetables that are not represented in the USDA dataset. A more accurate estimate

480 would require finer grain, in-depth consumption surveys stratified along socioeconomic lines. 
481 This would also help to reveal the full spectrum of crop varieties that people actually consume in 482 Oakland.

483 In terms of production, estimates of the local/seasonal share of crop production should be

484 fine-tuned using crop yield data specific to East Bay urban agroecosystems. No such data 485 currently exists in any comprehensive form. Moreover, not all vegetables would grow equally 486 well at every site, given site-specific soil quality and micro-climatic conditions. Such variability

487 would need to be considered once actual sites were selected. Because existing soil maps are too 488 coarse to capture such variability at the site scale, we did not include a soil assessment in our 489 GIS analysis.

490 Moreover, our three yield scenarios are realistic only if gardens were to be managed with 491 a level of professional attention to spacing, planting, weeding, irrigation, pest control, and 492 harvest. Community and school gardens that are not tended with the same level of care are 493 unlikely to attain such yields. Scenario 4 (100 ac devoted to urban agriculture) is arguably the 494 most realistic in that it represents a scale that City of Oakland officials might consider given 495 conflicting stakeholder needs (an issue we address in the Conclusion) and/or the difficulty they 496 might face in securing potential commercial or non-profit farm managers to farm a larger area. 497 Finally, our production estimates incorporate USDA loss estimates that are likely higher 498 than what might occur in a localized food system. Indeed, they reflect the average losses for 499 vegetables that travel more than 1,000 miles on average from farm to plate (Weber \& Matthews, 500 2008). Under a localized production system where more produce is sold at farm stands and

501 farmers' markets and less weight loss to processing, we might assume lower rates of loss

502 between retail and consumer. For this reason, our overall production estimates are likely 503 conservative. 


\section{$505 \quad$ 5.3. Future directions}

506 This study represents only a preliminary step in an ongoing effort to expand urban

507 agriculture in Oakland. The next step would be to prioritize site suitability. The sites identified in

508 this inventory were categorized based on size, slope, and aspect. While information on ground

509 cover, presence of a water meter, accessibility to public transportation, and proximity to schools

510 were included with each site listed in the Land Locator, these factors (selected by the advisory

511 committee) were not used to rank site suitability; rather, they were simply presented as relevant

512 data to help guide such decisions. A prioritization or ranking of sites for suitability should

513 include some or all of these factors, as well as others such as soil quality, tenure, access, and

514 waste disposal (Unger and Wooten 2006).

515 Soil quality, in particular, is an issue in urban areas. Many urban soils have high levels of

516 lead $(\mathrm{Pb})$ and other contaminants. This project led to the assessment of $\mathrm{Pb}$ at more than a

517 hundred sites identified in this inventory. Results indicated that $\mathrm{Pb}$ levels are lower than expected

518 across the city, but that levels are highly variable at each site and are dependent on a number of

519 variables including soil type, density of pre-1940s housing, distance to major roads, and levels of

520 soil carbon and soil phosphorus (McClintock, 2012). This data, along with EPA Brownfields and

521 California Department of Toxic Substances Control data, should figure centrally in future site

522 suitability assessment. Other indicators of soil quality, such as soil organic matter, cation

523 exchange capacity, clay content, and nutrient availability would also be useful. In many cases,

524 however, construction of raised beds and/or the importation of soil and compost may mitigate

525 many soil quality issues. 
526 Since the completion of the CTC inventory in 2009, several other land inventories have

527 been released. Each of these inventories includes additional variables that could be incorporated

528 into a finer grain analysis and that could help to narrow the overall suitability of a particular site.

529 Some of these analyses are more dependent on high-resolution geospatial data than others. The

530 Halifax inventory, for example, uses LiDAR data to model potential sun exposure at different

531 times of day in potential backyard gardens in several sample neighborhoods, and reports an

532 additional $22 \%$ loss of available space due to shading (Nipen, 2009). A Somerville

533 (Massachusetts) inventory includes soil type and population density in the analysis (Bickerdike,

534 DiLisio, Haskin, McCullagh, \& Pierce-Quinonez, 2010). One Cleveland inventory, conducted by

535 the Cleveland-Cuyahoga County Food Policy Coalition, includes presence of hydrological

536 features and soil, as well as proximity to community gardens greenhouses and other consumer

537 markets (Taggart et al., 2009). Furthermore, it excludes industrial and brownfields sites, as does

538 the New York assessment (Ackerman, 2012).

539 With the exception of a recent Cleveland study (Grewal \& Grewal, 2012), vacant land

540 inventories to date have not included economic variables. A suite of economic indicators such as

541 parcel values, crop values, job creation, and infrastructure costs would be necessary to conduct

542 cost-benefit analyses to compare urban agriculture to other land uses. At the same time, such an

543 econometric analysis would likely fail to capture the multiple — but difficult or impossible to

544 quantify — attributes that make parks and other green space valuable in urban landscapes, notably

545 the aesthetic, recreational, educational, and health benefits offered by such spaces.

546

547 6. Conclusion 
549 important step in an ongoing process to bring urban agriculture's potential to fruition in Oakland

550 and other cities. It will surely take a long time for cultivation to reach the 100 or 500 ac as

551 envisioned in the Low and High land use scenarios presented above. Ultimately, the delineation

552 of polygons is only a preliminary step in the long process of mapping the agricultural potential of

553 a city such as Oakland. Indeed, the politics of negotiating competing uses of vacant land is far

554 more complex than identifying potential sites of production. The real work in planning for urban

555 agriculture lies in identifying and negotiating the varied interests of multiple stakeholders.

$556 \quad$ As in any case of multiple land uses, such conflicting interests may hinder urban

557 agriculture at a particular site. For example, people who use the site for walking dogs, playing

558 Frisbee, flying kites, or picnicking would likely object to its conversion to agricultural use.

559 Similarly, "not-in-my-backyard" (NIMBY) sentiments from neighbors concerned over noise,

560 human or vehicle traffic, odors from compost or manure, or impact on property values may

561 prove a challenge to cultivation at particular sites. These conflicting interests and concerns must

562 figure centrally into public discussions over how much and which land to devote to urban

563 agriculture. In Oakland, all projects proposed on OPR land, for example, are required to go

564 through a lengthy approval process that includes several public comment periods where such

565 conflicts are heard.

566 The cultivation of private land ultimately depends on the will of the landowner.

567 Municipalities have little control over how a vacant parcel is to be used other than easing zoning

568 and permitting restrictions on urban agriculture (McClintock et al., 2012) or incentivizing

569 landowners to convert their property to agricultural use. A municipal government could waive

570 blight fines or provide property tax credits, for example, for vacant property owners allowing 
571 cultivation on their property, a policy exemplified by Maryland House Bill 1062 (Property Tax

572 Credit: Urban Agricultural Property) signed into law in May 2010.

573 While negotiating stakeholder interests ultimately determines how much vacant land is

574 used for urban agriculture, a vacant land inventory can help not only to identify possible

575 locations and posit their potential contribution to the food system, but can also help to embed the

576 socioecological landscape with alternative possibilities, a first step in realizing a vision of what

577 an alternative food system might look like. Geographer Kevin St. Martin (2009, p. 494) describes

578 such an approach as "a cartography of the commons that can effectively recast space as a site of

579 multiple economic possibilities and resources as the basis of community livelihoods." How this

580 vision is ultimately interpreted and mobilized — and by whom—will also necessarily become part

581 of this process. Additional analyses, as described above, may help stakeholders prioritize sites,

582 but the prioritization process itself will depend on how well differing views of land use are

583 negotiated and integrated and on how such spaces are valued. 


\section{References}

1. Ackerman, K. (2012). The Potential for Urban Agriculture in New York City: Growing Capacity, Food Security, and Green Infrastructure. New York, NY: Columbia University Urban Design Lab. Retrieved from http://www.urbandesignlab.columbia.edu/?pid=nyc$\underline{\text { urban-agriculture }}$

2. Balmer, K., Gill, J., Kaplinger, H., Miller, J., Paterson, M., Rhoads, A., ... Wall, T. (2005). The Diggable City: Making Urban Agriculture a Planning Priority. Portland, OR: Portland State University School of Urban Studies \& Planning. Retrieved from http://www.portlandoregon.gov/bps/42793

3. Beidleman, L., \& Kozloff, E. (2003). Plants of the San Francisco Bay Region: Mendocino to Monterey. Berkeley: University of California Press.

4. ACPHD. (2008). Life and Death from Unnatural Causes: Health and Social Inequity in Alameda County. Oakland, CA: Alameda County Public Health Department. Retrieved from http://www.acphd.org/media/53628/unnatcs2008.pdf

5. Bickerdike, C., DiLisio, C., Haskin, J., McCullagh, M., \& Pierce-Quinonez, M. (2010). From Factories to Fresh Food: Planning for Urban Agriculture in Somerville. Boston: Tufts University Agriculture, Food \& Environment Program. Retrieved from https://wikis.uit.tufts.edu/confluence/download/attachments/30411091/GWS+2010+Final+R eport.pdf

6. Casagrande, S. S., Wang, Y., Anderson, C., \& Gary, T. L. (2007). Have Americans increased their fruit and vegetable intake? The trends between 1988 and 2002. American Journal of Preventative Medicine, 32(4), 257-263. 
7. Colasanti, K., \& Hamm, M. (2010). Assssing the local food supply capacity of Detroit, Michigan. Journal of Agriculture, Food Systems, and Community Development, 1(2), 41-58.

8. Corburn, J. (2009). Toward the Healthy City: People, Places, and the Politics of Urban Planning. Cambridge, MA: MIT Press.

9. Costa, S., Palaniappan, M., Wong, A. K., Hays, J., Landeiro, C., \& Rongerude, J. (2002). Neighborhood Knowledge for Change: The West Oakland Environmental Indicators Project. Oakland: Pacific Institute for Studies in Development, Environment, and Security. Retrieved from http://www.pacinst.org/reports/environmental indicators/

10. Farfan-Ramirez, L., Olivera, M., Pascoe, K., \& Safinya-Davies, P. (2010). School Gardens Assessment: Alameda County Public Schools. Oakland: UC Cooperative Extension-Alameda County.

11. Grewal, S. S., \& Grewal, P. S. (2012). Can cities become self-reliant in food? Cities, 29(1), $1-11$.

12. Herrera, H., Khanna, N., \& Davis, L. (2009). Food systems and public health: The community perspective. Journal of Hunger and Environmental Nutrition, 4, 430-445.

13. Hodgson, K., Caton Campbell, M., \& Bailkey, M. (2011). Urban Agriculture: Growing Healthy, Sustainable Places. Washington: American Planning Association.

14. HOPE Collaborative. (2009). A Place with No Sidewalks: An Assessment of Food Access, the Built Environment and Local, Sustainable Economic Development in Ecological MicroZones in the City of Oakland, California in 2008. Oakland: HOPE Collaborative. Retrieved from http://www.hopecollaborative.net/images/stories/docs/hp_aplacewithn $\% 20$ sidewalks.pdf 
15. Horst, M. (2008). Growing Green: An Inventory of Public Lands Suitable for Gardening in Seattle, Washington. Seattle: University of Washington College of Architecture and Urban Planning. Retrieved from http://www.seattle.gov/Neighborhoods/ppatch/pubs/MHORST_GROWINGGREEN.pdf

16. Hou, J., Johnson, J. M., \& Lawson, L. J. (2009). Greening Cities, Growing Communities: Learning from Seattle's Urban Community Gardens. Seattle: University of Washington Press.

17. Innes, J. E., \& Booher, D. E. (2010). Planning with Complexity: An introduction to collaborative rationality for public policy. New York: Routledge.

18. Israel, B., Eng, E., Schulz, A., \& Parker, E. (2005). Methods in Community-Based Participatory Research for Health. New York: John Wiley \& Sons.

19. Jeavons, J. (2002). How to Grow More Vegetables (than you ever thought possible on less land than you can imagine). Berkeley: Ten Speed Press.

20. Kaethler, T. M. (2006). Growing Space: The Potential of Urban Agriculture in the City of Vancouver. Vancouver: University of British Columbia School of Community and Regional Planning. Retrieved from http://www.urbanfarmers.ca/publications/growing-space-potentialurban-agriculture-city-vancouver

21. MacRae, R., Gallant, E., Patel, S., Michalak, M., Bunch, M., \& Schaffner, S. (2010). Could Toronto provide $10 \%$ of its fresh vegetable requirements from within its own boundaries? Matching consumption requirements with growing spaces. Journal of Agriculture, Food Systems, and Community Development, 1(2), 105-127. 
22. Marks, A. (2008, May 16). As food prices shoot up, so do backyard gardens. Christian Science Monitor. Retrieved from http://www.csmonitor.com/USA/Society/2008/0516/p01s01-ussc.html

23. McClintock, N. (2011). From Industrial Garden to Food Desert: Demarcated Devalution in the Flatlands of Oakland, California. In A. H. Alkon \& J. Agyeman (Eds.), Cultivating Food Justice: Race, Class, and Sustainability (pp. 89-120). Cambridge, MA: MIT Press.

24. McClintock, N. (2012). Assessing soil lead contamination at multiple scales in Oakland, California: Implications for urban agriculture and environmental justice. Applied Geography, $35(1-2), 460-473$.

25. McClintock, N., \& Cooper, J. (2009). Cultivating the Commons: An Assessment of the Potential for Urban Agriculture on Oakland's Public Land. Oakland: Institute for Food \& Development Policy/City Slicker Farms/HOPE Collaborative. Retrieved from http://www.hopecollaborative.net/images/stories/docs/hp_cultivatingthecommons.pdf

26. McClintock, N., Wooten, H., \& Brown, A. (2012). Toward a food policy "first step" in Oakland, California: A food policy council's efforts to promote urban agriculture zoning. Journal of Agriculture, Food Systems, and Community Development, 2(4), 15-42.

27. Mendes, W., Balmer, K., Kaethler, T., \& Rhoads, A. (2008). Using Land Inventories to Plan for Urban Agriculture: Experiences from Portland and Vancouver. Journal of the American Planning Association, 74(4), 435-449.

28. Metzger, E. S., \& Lendvay, J. M. (2006). Seeking Environmental Justice through Public Participation: A Community-Based Water Quality Assessment in Bayview Hunters Point. Environmental Practice, 8, 104-114. 
29. Minkler, M., \& Wallerstein, N. (2003). Community-Based Participatory Research for Health. San Francisco: Jossey-Bass.

30. Muller, M., Tagtow, A., Roberts, S. L., \& MacDougall, E. (2009). Aligning Food Systems Policies to Advance Public Health. Journal of Hunger \& Environmental Nutrition, 4(3\&4), $225-240$.

31. Nipen, A. (2009). Assessing the Available Land Area for Urban Agriculture on the Halifax Peninsula. Halifax: Dalhousie University Environmental Science Program. Retrieved from http://environmental.science.dal.ca/Files/Environmental\%20Programs/ENVS_4900 thesis_p ro/a nipen.pdf

32. NOAA. (2004). Climatography of the United States No. 20, 1971-2000, Oakland Museum, CA Station. Asheville, NC: National Oceanic and Atmospheric Administration. Retrieved from http://www.ggweather.com/climate/oakland.pdf

33. Nordahl, D. (2009). Public Produce: The New Urban Agriculture. Washington: Island Press.

34. OFPC. (2010). Transforming Oakland Food System: A Plan for Action. Oakland: Oakland Food Policy Council / Food First. Retrieved from http://www.oaklandfood.org/home/policy recommendations

35. Petersen, D., Minkler, M., Vasquez, V. B., \& Baden, A. C. (2006). Community-Based Participatory Research as a Tool for Policy Change: A Case Study of the Southern California Environmental Justice Collaborative. Review of Policy Research, 23(2), 339-353.

36. Pothukuchi, K. (2009). Community and Regional Food Planning: Building Institutional Support in the United States. International Planning Studies, 14(4), 349-367.

37. Redwood, M. (Ed.). (2011). Agriculture in Urban Planning: Generating Livelihoods and Food Security. London: Earthscan. 
38. Self, R. O. (2003). American Babylon: Race and the Struggle for Postwar Oakland. Princeton: Princeton University Press.

39. Sloan, D. (2006). Geology of the San Francisco Bay Region. Berkeley: University of California Press.

40. St. Martin, K. (2009). Toward a cartography of the commons: Constituting the poltical and economic possibilities of place. The Professional Geographer, 61(4), 493-507.

41. Taggart, M., Chaney, M., \& Meaney, D. (2009). Vacant Land Inventory for Urban Agriculture. Cleveland, OH: Cleveland-Cuyahoga Food Policy Coalition. Retrieved from http://cccfoodpolicy.org/document/vacant-land-inventory-urban-agriculture-report-urbanland-ecology-conference

42. Taylor, J. R., \& Lovell, S. T. (2012). Mapping public and private spaces of urban agriculture in Chicago through the analysis of high-resolution aerial images in Google Earth. Landscape and Urban Planning, 108(1), 57-70.

43. U.S. Census Bureau. (2010). United States Decennial Census. Retrieved from http://factfinder2.census.gov/

44. Unger, S., \& Wooten, H. (2006). A Food Systems Assessment for Oakland, CA: Towards a Sustainable Food Plan. Oakland Mayor's Office of Sustainabiltiy. Retrieved from http://oaklandfoodsystem.pbworks.com

45. USDA (2005). National Agriculture Imagery Program. United States Department of Agriculture. Retrieved from http://datagateway.nrcs.usda.gov/

46. USDA. (2010). Loss-Adjusted Food Availability Data Sets. United States Department of Agriculture Economic Research Service. Retrieved from http://www.ers.usda.gov/Data/FoodConsumption/FoodGuideIndex.htm 
47. Walker, R. (2001). Industry builds the city: the suburbanization of manufacturing in the San Francisco Bay Area, 1850-1940. Journal of Historical Geography, 27(1), 36-57.

48. Weber, C. L., \& Matthews, H. S. (2008). Food-Miles and the Relative Climate Change Impacts of Food Choices in the United States. Environmental Science \& Technology, 42(10), $3508-3513$.

49. Welch, L. E. (1981). Soil Survey of Alameda County, Western Part. United States Department of Agriculture Soil Conservation Service. Retrieved from http://soils.usda.gov/survey/online_surveys/california/

50. Welty, E. (2010). Mapping the Agricultural Potential of Urban Arable Land in Boulder, CO. Boulder, CO: Colorado University Department of Environmental Studies.

51. Wooten, H. (2008). Food System Meta-Analysis for Oakland, California. Oakland: Public Health Law \& Policy / Food First. Retrieved from http://www.foodfirst.org/en/node/2397 


\section{List of Tables}

Table 1: Potentially arable vacant or underutilized public land in Oakland, California

Table 2: Oakland's recommended vegetable needs

Table 3: Total and locally possible vegetable production (including losses) necessary to meet estimated existing and recommended consumption needs in Oakland

Table 4: Land area disaggregated by slope and aspect

Table 5 Potential contribution of urban agriculture on public land to Oakland's estimated and recommended vegetable needs under three management types and four land use scenarios

Table 6. Size distribution of privately owned vacant land in Oakland 
Table 1: Potentially arable vacant or underutilized public land in Oakland, California

\begin{tabular}{|c|c|c|c|c|c|c|c|}
\hline \multirow[b]{2}{*}{$\begin{array}{l}\text { Land type by level of government: } \\
\text { Landowner or managing agency }\end{array}$} & \multicolumn{3}{|c|}{ Total public land } & \multicolumn{4}{|c|}{$\begin{array}{c}\text { Public land w/ urban agriculture } \\
\text { potential }\end{array}$} \\
\hline & $\begin{array}{r}\text { No. } \\
\text { parcels }\end{array}$ & ac & ha & $\begin{array}{r}\text { No. } \\
\text { parcels }\end{array}$ & ac & ha & $\begin{array}{r}\% \text { of } \\
\text { total } \\
\text { area }\end{array}$ \\
\hline \multicolumn{8}{|l|}{ Municipal: } \\
\hline City of Oakland & 1,167 & $6,659.4$ & $2,695.0$ & 206 & 232.7 & 94.2 & 19.4 \\
\hline Oakland Parks \& Recreation (OPR) & $* *$ & ** & & 266 & 629.1 & 254.6 & 52.5 \\
\hline Redevelopment Agency & 104 & 32.9 & 13.3 & 8 & 2.1 & 0.8 & 0.2 \\
\hline Housing Authority & 343 & 127.9 & 51.8 & 13 & 2.3 & 0.9 & 0.2 \\
\hline Oakland Unified School District & 165 & 493.2 & 199.6 & 10 & 5.8 & 2.3 & 0.5 \\
\hline \multicolumn{8}{|l|}{ County: } \\
\hline Alameda Co. Flood Control & 114 & 50.9 & 20.6 & 25 & 8.9 & 3.6 & 0.7 \\
\hline Alameda Co. Superintendent of Schools & 1 & 1.8 & 0.7 & 1 & 0.6 & 0.2 & 0.1 \\
\hline Peralta Community College District & 23 & 188.9 & 76.4 & 24 & 36.5 & 14.8 & 3.0 \\
\hline AC Transit District & 8 & 23.8 & 9.6 & 1 & 0.6 & 0.2 & 0.1 \\
\hline County of Alameda & 29 & 159.8 & 64.7 & 1 & 8.9 & 3.6 & 0.7 \\
\hline \multicolumn{8}{|l|}{ Regional: } \\
\hline Bay Area Rapid Transit (BART) & 100 & 59.4 & 24.0 & 8 & 1.9 & 0.8 & 0.2 \\
\hline East Bay Municipal Utilities District & 115 & 405.0 & 163.9 & 48 & 28.0 & 11.3 & 2.3 \\
\hline East Bay Regional Parks District & 100 & 835.8 & 338.2 & 65 & 109.0 & 44.1 & 9.1 \\
\hline \multicolumn{8}{|l|}{ State: } \\
\hline University of California Regents & 19 & 748.8 & 303.0 & 41 & 92.6 & 37.5 & 7.7 \\
\hline State of California & 248 & 195.0 & 78.9 & 39 & 42.7 & 17.3 & 3.6 \\
\hline \multicolumn{8}{|l|}{ Federal: } \\
\hline Amtrak & 8 & 19.1 & 7.7 & 0 & 0 & 0 & 0 \\
\hline US Postal Service & 6 & 9.2 & 3.7 & 0 & 0 & 0 & 0 \\
\hline Other federal land & 21 & 496.7 & 201.0 & 0 & 0 & 0 & 0 \\
\hline Total $^{++}$ & 2,551 & $10,013.0$ & $4,052.1$ & 756 & $1,201.7$ & 486.3 & 100 \\
\hline
\end{tabular}

** Oakland Parks and Recreation (OPR) land is included in City of Oakland total listed in the row above.

++ The sum of individual rows may slightly exceed the total due to rounding 
Table 2: Oakland's recommended vegetable needs

\begin{tabular}{|c|c|c|c|c|c|c|c|}
\hline \multirow{2}{*}{\multicolumn{2}{|c|}{$\begin{array}{l}\text { Oakland population } \\
(2010)^{\mathrm{a}}\end{array}$}} & \multicolumn{4}{|c|}{ - } & \multicolumn{2}{|c|}{------- Citywide ------- } \\
\hline & & cups / day ${ }^{b}$ & (g / day) & lbs / year & (kg / year) & tons / year & (Mg/ year) \\
\hline \multicolumn{8}{|l|}{ Males } \\
\hline$<5 \mathrm{yrs}$ & 13,396 & 1 & (229) & 183 & (83.6) & 1,222 & $(1,108.6)$ \\
\hline 5 to 9 & 11,708 & 1.5 & (343) & 274 & (125.2) & 1,603 & $(1,454.2)$ \\
\hline 10 to 14 & 10,500 & 2.5 & (571) & 456 & (208.4) & 2,395 & $(2,172.7)$ \\
\hline 15 to 19 & 11,293 & 3 & (680) & 548 & (248.2) & 3,091 & $(2,804.1)$ \\
\hline 20 to 34 & 46,201 & 3.5 & (800) & 639 & (292.0) & 14,755 & $(13,385.5)$ \\
\hline 35 to 79 & 91,836 & 3 & (680) & 548 & (248.2) & 25,140 & $(22,806.6)$ \\
\hline$>79$ yrs & 4,585 & 2.5 & (571) & 456 & (414.1) & 1,046 & (948.9) \\
\hline \multicolumn{8}{|l|}{ Females } \\
\hline$<5 \mathrm{yrs}$ & 12,703 & 1 & (229) & 183 & (83.6) & 1,159 & $(1,051.4)$ \\
\hline 5 to 9 & 11,286 & 1.5 & (343) & 274 & (125.2) & 1,545 & $(1,401.6)$ \\
\hline 10 to 14 & 10,325 & 2 & (457) & 365 & (166.8) & 1,884 & $(1,709.1)$ \\
\hline 15 to 19 & 11,163 & 2.5 & (571) & 456 & (208.4) & 2,547 & $(2,310.6)$ \\
\hline 20 to 44 & 79,322 & 2.5 & (571) & 456 & (208.4) & 18,095 & $(16,415.5)$ \\
\hline 45 to 64 & 51,250 & 2.5 & (571) & 456 & (208.4) & 11,691 & $(10.605 .9)$ \\
\hline$>64 \mathrm{yrs}$ & 25,156 & 2 & (457) & 365 & (166.8) & 4,591 & $(4,164.9)$ \\
\hline Total & 390,724 & & & & & 90,766 & $(82,341.5)$ \\
\hline
\end{tabular}

${ }^{a}$ Data source: (U.S. Census Bureau, 2010)

${ }^{\mathrm{b}}$ Data source: (USDA, 2010) 
Table 3: Total and locally possible vegetable production (including losses) necessary to meet estimated existing and recommended consumption needs in Oakland

\section{Production needed to meet:}

Estimated current
consumption $\quad \begin{gathered}\text { Recommended } \\ \text { consumption }\end{gathered}$

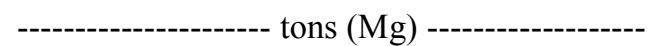

\begin{tabular}{llc}
\hline Total production needed (including losses) & $28,884(26,203.1)$ & $137,016(124,298.8)$ \\
$\begin{array}{l}\text { Possible local/seasonal share of total production } \\
\text { (including losses) }\end{array}$ & $23,954(21,730.7)$ & $113,630(103,083.4)$ \\
\hline
\end{tabular}


Table 4: Land area disaggregated by slope and aspect

\begin{tabular}{|c|c|c|c|c|}
\hline & \multicolumn{2}{|c|}{ Area $* *$} & \multirow{2}{*}{$\%$ total } & \multirow{2}{*}{ Description } \\
\hline & ac & (ha) & & \\
\hline Slope & & & & \\
\hline Under $10 \%$ & 409.6 & $(165.8)$ & 34.1 & Flat terrain to gradual slope $(<5.7$ degrees $)$ \\
\hline 10 to $20 \%$ & 211.0 & (85.3) & 17.6 & Gradual to moderate (5.7 to 11.3 degrees) \\
\hline 20 to $30 \%$ & 207.2 & $(83.9)$ & 17.2 & Moderate to steep (11.3 to 16.7 degrees) \\
\hline Over $30 \%$ & 374.1 & $(151.4)$ & 31.1 & Very steep ( $>16.7$ degrees) \\
\hline Total & $1,201.9$ & (486.4) & 100.0 & \\
\hline Aspect & & & & \\
\hline NW-N-NE & 140.0 & (56.7) & 11.6 & Often shaded \\
\hline W-SW-S-SE-E & $1,061.9$ & $(429.7)$ & 88.3 & Receives more direct sunlight \\
\hline $\begin{array}{l}\text { Total } \\
\text { Aspect + Slope }\end{array}$ & $1,201.9$ & (486.4) & 100.0 & \\
\hline Optimal & 730.1 & $(295.5)$ & 60.1 & Western, southern, or eastern exposure, slope under $30 \%$ \\
\hline Less Desirable & 471.8 & $(190.9)$ & 39.9 & Northern exposure, slope greater than $30 \%$ \\
\hline Total & 1,201.9 & (486.4) & 100.0 & \\
\hline
\end{tabular}

** Total difference in area $(0.2 \mathrm{ac})$ is due to conversion from vector to raster data. Total\% may exceed 100 due to rounding. 
Table 5. Potential contribution of urban agriculture on public land to Oakland's estimated and recommended vegetable needs under three management types and four land use scenarios

\begin{tabular}{|c|c|c|c|c|c|c|c|}
\hline \multirow{3}{*}{$\begin{array}{l}\text { Consumption } \\
\text { level }\end{array}$} & \multirow{3}{*}{$\begin{array}{c}\text { Agricultural } \\
\text { management } \\
\text { practice }\end{array}$} & \multirow[b]{2}{*}{$\begin{array}{l}\text { Avg. } \\
\text { yield }\end{array}$} & \multirow[b]{2}{*}{$\begin{array}{c}\text { Area } \\
\text { needed }\end{array}$} & \multicolumn{4}{|c|}{--------- Land use scenario a } \\
\hline & & & & $\begin{array}{c}\mathbf{1} \\
\text { All } \\
828 \mathrm{ac} \\
(335.1 \mathrm{ha})\end{array}$ & $\begin{array}{c}2 \\
\text { Optimal } \\
730 \mathrm{ac} \\
(295.4 \mathrm{ha})\end{array}$ & $\begin{array}{c}\text { 3 } \\
\text { High } \\
500 \mathrm{ac} \\
(202.3 \mathrm{ha})\end{array}$ & $\begin{array}{c}\mathbf{4} \\
\text { Low } \\
100 \mathrm{ac} \\
(40.5 \mathrm{ha})\end{array}$ \\
\hline & & $\begin{array}{l}\text { tons/ac } \\
(\mathrm{Mg} / \mathrm{ha})\end{array}$ & $\begin{array}{l}\text { Ac } \\
\text { (ha) }\end{array}$ & \multicolumn{4}{|c|}{---- $\%$ contribution to vegetable needs ${ }^{\mathrm{b}}$---- } \\
\hline \multirow{3}{*}{$\begin{array}{l}\text { Current } \\
\text { (estimated) }\end{array}$} & Conventional & $\begin{array}{c}10 \\
(22.4)\end{array}$ & $\begin{array}{c}2,582 \\
(1,044.9)\end{array}$ & 24.1 & 21.2 & 14.5 & 2.9 \\
\hline & $\begin{array}{c}\text { Biointensive - } \\
\text { Low }\end{array}$ & $\begin{array}{c}15 \\
(33.6)\end{array}$ & $\begin{array}{c}1,722 \\
(696.9)\end{array}$ & 36.1 & 31.8 & 21.8 & 4.4 \\
\hline & $\begin{array}{c}\text { Biointensive - } \\
\text { Med }\end{array}$ & $\begin{array}{c}25 \\
(56.0)\end{array}$ & $\begin{array}{c}1,033 \\
(418.0)\end{array}$ & 60.1 & 53.0 & 36.3 & 7.3 \\
\hline \multirow{3}{*}{ Recommended } & Conventional & $\begin{array}{c}10 \\
(22.4)\end{array}$ & $\begin{array}{c}12,250 \\
(4,957.4)\end{array}$ & 5.1 & 4.5 & 3.1 & 0.6 \\
\hline & $\begin{array}{c}\text { Biointensive - } \\
\text { Low }\end{array}$ & $\begin{array}{c}15 \\
(33.6)\end{array}$ & $\begin{array}{c}8,167 \\
(3,305.1)\end{array}$ & 7.6 & 6.7 & 4.6 & 0.9 \\
\hline & $\begin{array}{c}\text { Biointensive - } \\
\text { Med }\end{array}$ & $\begin{array}{c}25 \\
(56.0)\end{array}$ & $\begin{array}{c}4,900 \\
(1,983.0)\end{array}$ & 12.7 & 11.2 & 7.7 & 1.5 \\
\hline
\end{tabular}

${ }^{a}$ Scenario 1 includes all identified publicly owned vacant or underutilized public land with a slope $<30 \%$. Scenario 2 removes NW, N, and NE-facing slopes from the Scenario 1 total area. Scenarios 3 and 4 are based on arbitrary values (high and low, respectively) of land area that might be converted to crop production via a municipal policy or initiative.

${ }^{b}$ assumes that $75 \%$ of land in each scenario will be used for crop production 
Table 6. Size distribution of privately owned vacant land in Oakland

\begin{tabular}{cccccc}
\hline \multicolumn{2}{c}{ Parcel Size } & Potential use & No. parcels & \multicolumn{2}{c}{ Total area } \\
ac & (ha) & ac & (ha) \\
\hline $100 \mathrm{ft}^{2}$ to $0.25 \mathrm{ac}$ & $\left(9.3 \mathrm{~m}^{2}\right.$ to 0.1 ha) & Community garden & 2,484 & 289 & $(117.0)$ \\
0.25 to $0.5 \mathrm{ac}$ & $(0.1$ to 0.2$)$ & $\begin{array}{c}\text { Community garden } \\
\text { market garden }\end{array}$ & 338 & 113 & $(45.7)$ \\
0.5 to $1 \mathrm{ac}$ & $(0.2$ to 0.4$)$ & Market garden & 115 & 81 & $(32.8)$ \\
1 to $5 \mathrm{ac}$ & $(0.4$ to 2.0$)$ & Urban farm & 56 & 119 & $(48.2)$ \\
$>5 \mathrm{ac}$ & $(>2.0)$ & Urban farm & 15 & 262 & $(106.0)$ \\
Total & & & $\mathbf{3 , 0 0 8}$ & $\mathbf{8 6 4}$ & $\mathbf{( 3 4 9 . 6 )}$ \\
Total (< & & & $\mathbf{3 3 7}$ & $\mathbf{( 1 3 6 . 4 )}$ \\
\hline
\end{tabular}




\section{List of Figures}

Figure 1: The hills and flatlands of Oakland, California. Note that the industrial areas (blue) are located in the flatlands along the waterfront. Freeways are labeled in red and downtown (central business district) labeled as “CBD”.

Figure 2: Examples of (a) vacant land and (b) underutilized parks in Oakland included in the inventory.

Figure 3: Vacant or underutilized public and privately owned land in Oakland. Sites with the greatest agricultural potential are those with slopes less than $30 \%$ (orange and purple). 


\section{List of Appendices}

Appendix A: Estimated and recommended vegetable consumption in Oakland and possible local/seasonal share

Appendix B: Average conventional and biointensive yields and farm-to-table losses 
Appendix A: Estimated and recommended vegetable consumption in Oakland and possible local/seasonal share

\begin{tabular}{|c|c|c|c|c|c|c|c|}
\hline \multirow{3}{*}{ Crop } & \multirow{3}{*}{$\begin{array}{c}\text { US per capita } \\
\text { consumption } \\
\text { (USDA 2010) } \\
(\mathrm{lbs} / \text { year) }\end{array}$} & \multicolumn{2}{|c|}{---------- Oakland ----------- } & \multirow{3}{*}{$\begin{array}{c}\text { Annual } \\
\text { months of } \\
\text { production }\end{array}$} & \multirow{3}{*}{$\begin{array}{c}\text { Possible } \\
\text { local/seasonal } \\
\text { availability } \\
(\%)\end{array}$} & \multicolumn{2}{|c|}{ Possible local/seasonal share of: } \\
\hline & & \multirow{2}{*}{$\begin{array}{c}\text { Estimated current } \\
\text { consumption }\end{array}$} & \multirow{2}{*}{$\begin{array}{l}\text { Recommended } \\
\text { consumption }\end{array}$} & & & $\begin{array}{l}\text { Estimated current } \\
\text { consumption }\end{array}$ & $\begin{array}{l}\text { Recommended } \\
\text { consumption }\end{array}$ \\
\hline & & & & & & ---------- (tons & -------- \\
\hline Artichokes & 0.2 & 42 & 197 & 10 & 83 & 35 & 164 \\
\hline Asparagus & 0.3 & 57 & 269 & 5 & 42 & 24 & 112 \\
\hline Bell peppers & 4.6 & 908 & 4,308 & 7 & 58 & 530 & 2,513 \\
\hline Broccoli & 1.8 & 360 & 1,710 & 12 & 100 & 360 & 1,710 \\
\hline Brussels sprouts & 0.1 & 27 & 129 & 12 & 100 & 27 & 129 \\
\hline Cabbage & 3.9 & 761 & 3,611 & 12 & 100 & 761 & 3,611 \\
\hline Carrots & 5.5 & 1,067 & 5,062 & 12 & 100 & 1,067 & 5,062 \\
\hline Cauliflower & 0.2 & 47 & 225 & 10 & 83 & 39 & 187 \\
\hline Celery & 3.8 & 737 & 3,498 & 9 & 75 & 553 & 2,624 \\
\hline Collard greens & 0.1 & 28 & 132 & 11 & 92 & 26 & 121 \\
\hline Sweet corn & 0.3 & 64 & 304 & 0 & 0 & 0 & 0 \\
\hline Cucumbers & 2.9 & 570 & 2,703 & 6 & 50 & 285 & 1,352 \\
\hline Eggplant & 0.3 & 60 & 284 & 4 & 33 & 20 & 95 \\
\hline Escarole /endive & 0.1 & 18 & 83 & 12 & 100 & 18 & 83 \\
\hline Garlic & 1.3 & 253 & 1,198 & 12 & 100 & 253 & 1,198 \\
\hline Head lettuce & 11.4 & 2,226 & 10,559 & 12 & 100 & 2,226 & 10,559 \\
\hline Kale & 0.1 & 15 & 70 & 12 & 100 & 15 & 70 \\
\hline Leaf lettuce & 4.9 & 961 & 4,556 & 12 & 100 & 961 & 4,556 \\
\hline Lima beans & 0.0 & 2 & 8 & 0 & 0 & 0 & 0 \\
\hline Mushrooms & 1.6 & 316 & 1,501 & 12 & 100 & 316 & 1,501 \\
\hline Mustard greens & 0.2 & 29 & 140 & 6 & 50 & 15 & 70 \\
\hline Okra & 0.2 & 31 & 149 & 0 & 0 & 0 & 0 \\
\hline Onions & 9.3 & 1,821 & 8,637 & 12 & 100 & 1,821 & 8,637 \\
\hline Potatoes & 27.0 & 5,271 & 25,001 & 11 & 92 & 4,831 & 22,918 \\
\hline Pumpkins & 1.9 & 362 & 1716 & 4 & 33 & 121 & 572 \\
\hline Radishes & 0.3 & 51 & 241 & 12 & 100 & 51 & 241 \\
\hline Snap beans & 1.0 & 201 & 953 & 12 & 100 & 201 & 953 \\
\hline Spinach & 0.6 & 126 & 599 & 12 & 100 & 126 & 599 \\
\hline Squash & 2.2 & 423 & 2,009 & 5 & 42 & 176 & 837 \\
\hline Sweet potatoes & 1.4 & 281 & 1,332 & 0 & 0 & 0 & 0 \\
\hline Tomatoes & 10.2 & 1,997 & 9,473 & 6 & 50 & 999 & 4,737 \\
\hline Turnip greens & 0.1 & 22 & 106 & 7 & 58 & 13 & 62 \\
\hline Fresh vegetables & 97.9 & 19,134 & 90,766 & & 83 & 15,869 & 75,274 \\
\hline
\end{tabular}


Appendix B: Average conventional and biointensive yields and farm-to-table losses

\begin{tabular}{|c|c|c|c|c|c|c|c|}
\hline \multirow{3}{*}{ Crop } & \multicolumn{3}{|c|}{ 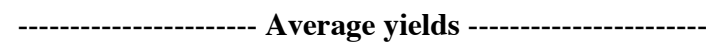 } & \multirow{3}{*}{$\begin{array}{c}\text { Farm } \\
\text { to retail }\end{array}$} & \multirow[b]{2}{*}{$\begin{array}{c}\text { Retail } \\
\text { to consumer }\end{array}$} & age losses & \multirow{3}{*}{$\begin{array}{c}\text { Total } \\
\text { farm to table } \\
\text { loss }^{c}\end{array}$} \\
\hline & Conventional $^{\mathrm{a}}$ & $\begin{array}{c}\text { Biointensive } \\
(\text { low })^{b}\end{array}$ & $\begin{array}{c}\text { Biointensive } \\
\text { (medium) }^{\mathrm{b}}\end{array}$ & & & $\begin{array}{c}\text { Inedible } \\
\text { share }^{c}\end{array}$ & \\
\hline & \multicolumn{3}{|c|}{ 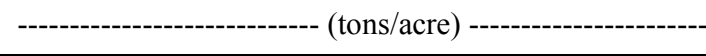 } & & ------------------- & $(\%)----$ & \\
\hline Artichokes & 6.1 & nd & nd & 7 & 19 & 60 & 49 \\
\hline Asparagus & 1.5 & 2.1 & 4.1 & 9 & 9 & 47 & 57 \\
\hline Bell peppers & 15.0 & 7.8 & 15.7 & 8 & 8 & 18 & 73 \\
\hline Broccoli & 7.5 & 5.7 & 11.3 & 8 & 12 & 39 & 59 \\
\hline Brussels sprouts & 9.0 & 15.5 & 30.9 & 8 & 19 & 10 & 71 \\
\hline Cabbage & 20.0 & 20.9 & 41.8 & 7 & 14 & 20 & 68 \\
\hline Carrots & 15.0 & 21.8 & 43.6 & 3 & 5 & 11 & 83 \\
\hline Cauliflower & 9.0 & 9.6 & 19.2 & 8 & 14 & 61 & 50 \\
\hline Celery & 36.5 & 52.3 & 104.5 & 7 & 5 & 11 & 80 \\
\hline Collard greens & 8.5 & 20.9 & 41.8 & 12 & 38 & 43 & 45 \\
\hline Cucumbers & 12.0 & 34.4 & 68.8 & 8 & 6 & 27 & 69 \\
\hline Eggplant & 10.0 & 11.8 & 23.5 & 10 & 21 & 19 & 63 \\
\hline Escarole /endive & 7.8 & nd & nd & 10 & 47 & 14 & 54 \\
\hline Garlic & 8.5 & 13.1 & 26.1 & 19 & 7 & 14 & 69 \\
\hline Head lettuce & 18.0 & 16.3 & 32.7 & 7 & 9 & 16 & 74 \\
\hline Kale & 10.0 & 16.6 & 33.1 & 12 & 39 & 39 & 46 \\
\hline Leaf lettuce & 11.5 & 29.4 & 58.8 & 7 & 14 & 21 & 68 \\
\hline Mushrooms & 35.9 & nd & nd & 6 & 13 & 3 & 81 \\
\hline Mustard greens & 7.5 & 39.2 & 78.4 & 12 & 63 & 27 & 43 \\
\hline Onions & 22.5 & 21.8 & 43.6 & 6 & 10 & 10 & 78 \\
\hline Potatoes & 18.5 & 21.8 & 43.6 & 4 & 7 & 0 & 90 \\
\hline Pumpkins & 12.0 & 10.5 & 20.9 & 10 & 11 & 30 & 63 \\
\hline Radishes & 11.5 & 21.8 & 43.6 & 3 & 21 & 10 & 73 \\
\hline Snap beans & 5.0 & 6.5 & 13.1 & 6 & 18 & 12 & 71 \\
\hline Spinach & 8.0 & 10.9 & 21.8 & 12 & 14 & 28 & 61 \\
\hline Squash & 10.0 & 10.9 & 21.8 & 10 & 13 & 17 & 69 \\
\hline Tomatoes & 15.0 & 21.8 & 43.6 & 15 & 13 & 9 & 70 \\
\hline Turnip greens & nd & 5.4 & 10.9 & 12 & 41 & 30 & 49 \\
\hline Fresh vegetables & 13.2 & 15.4 & 30.8 & 9 & 18 & 24 & 63 \\
\hline
\end{tabular}

Data sources: ${ }^{\mathrm{a}}$ USDA 2010; ${ }^{\mathrm{b}}$ Jeavons 2002; ${ }^{\mathrm{c}}$ USDA 201 
Figure 1
Click here to download high resolution image

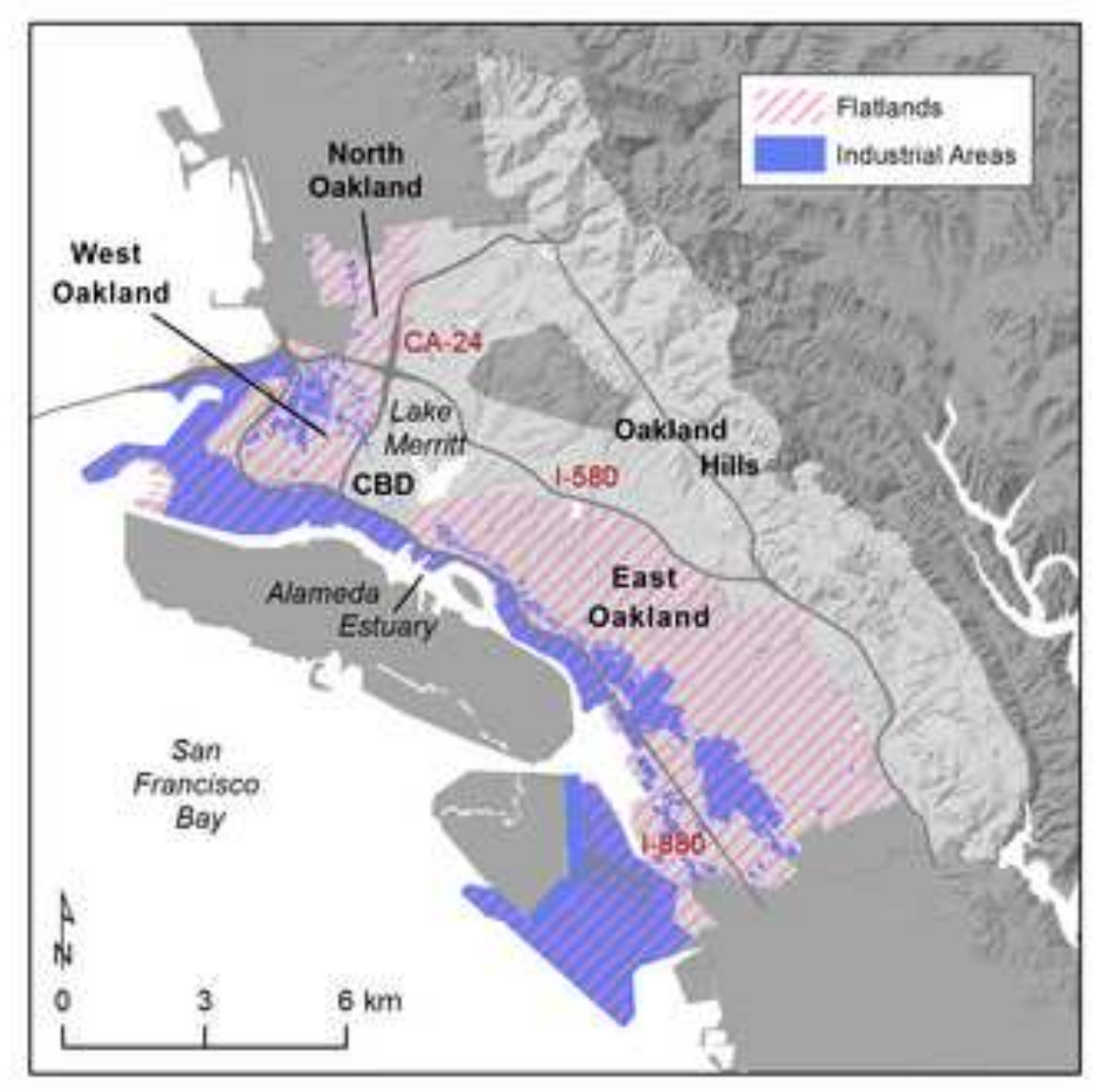




\section{Click here to download high resolution image}

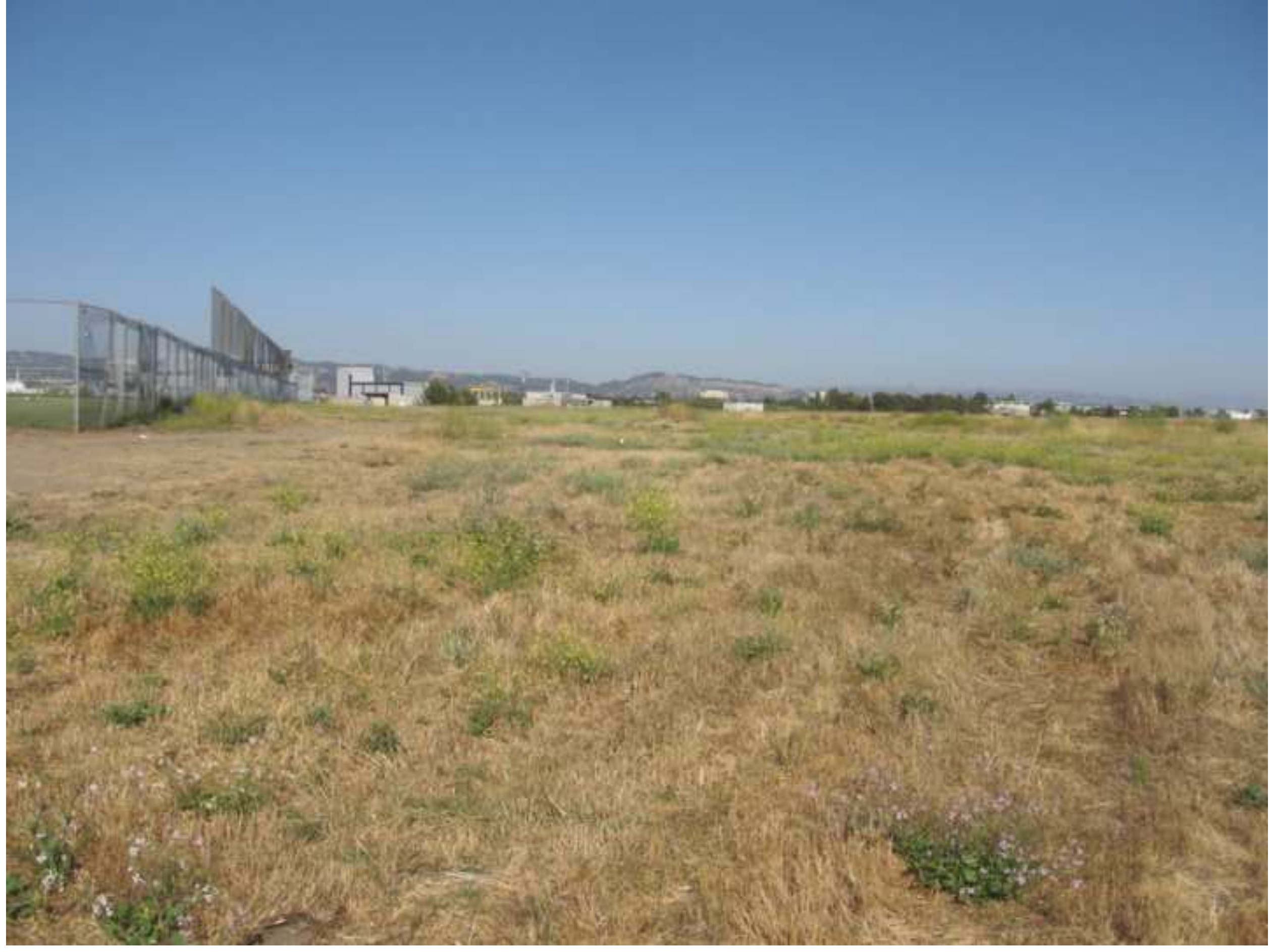




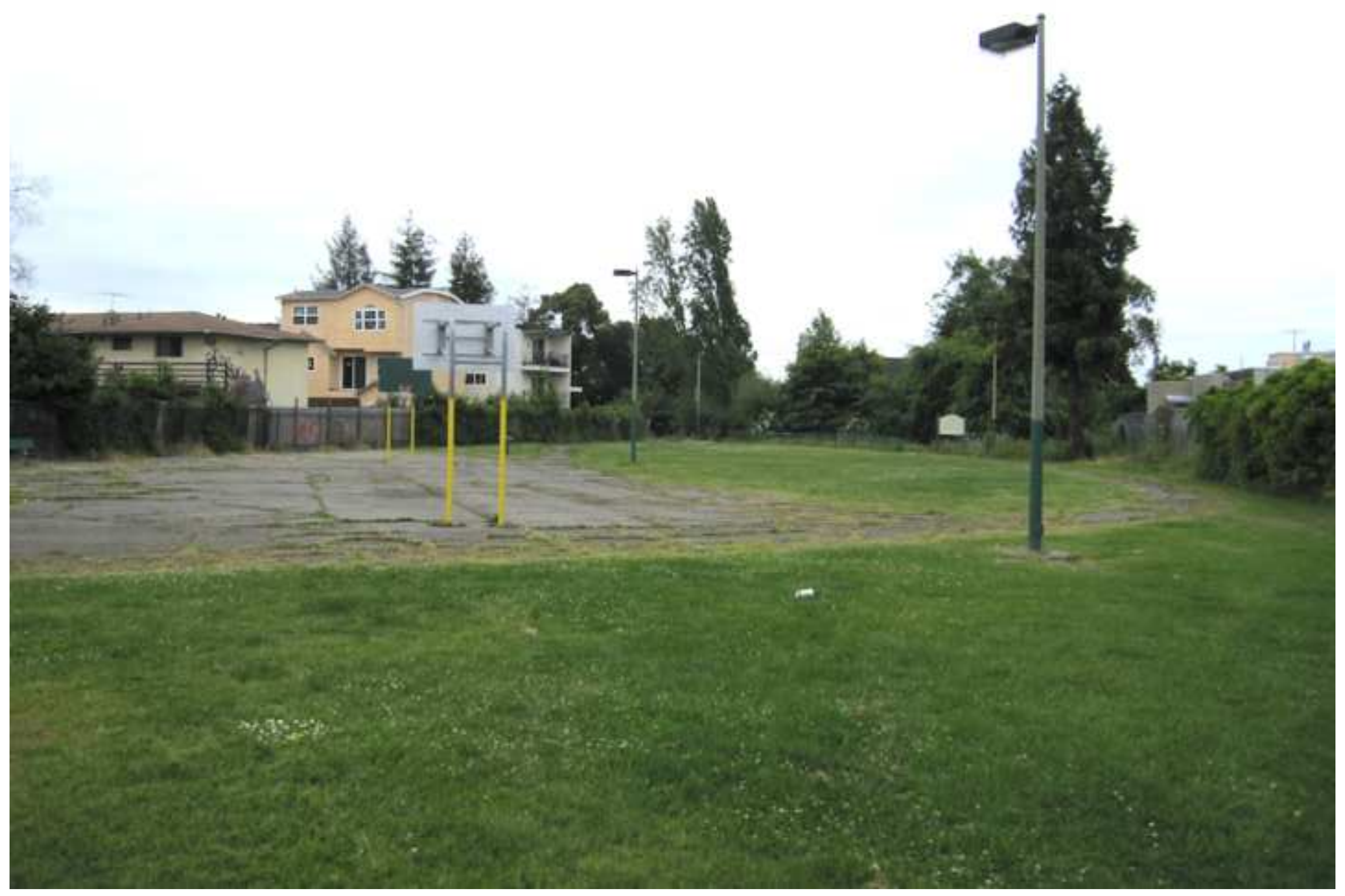




\section{Figure 3}

Click here to download high resolution image

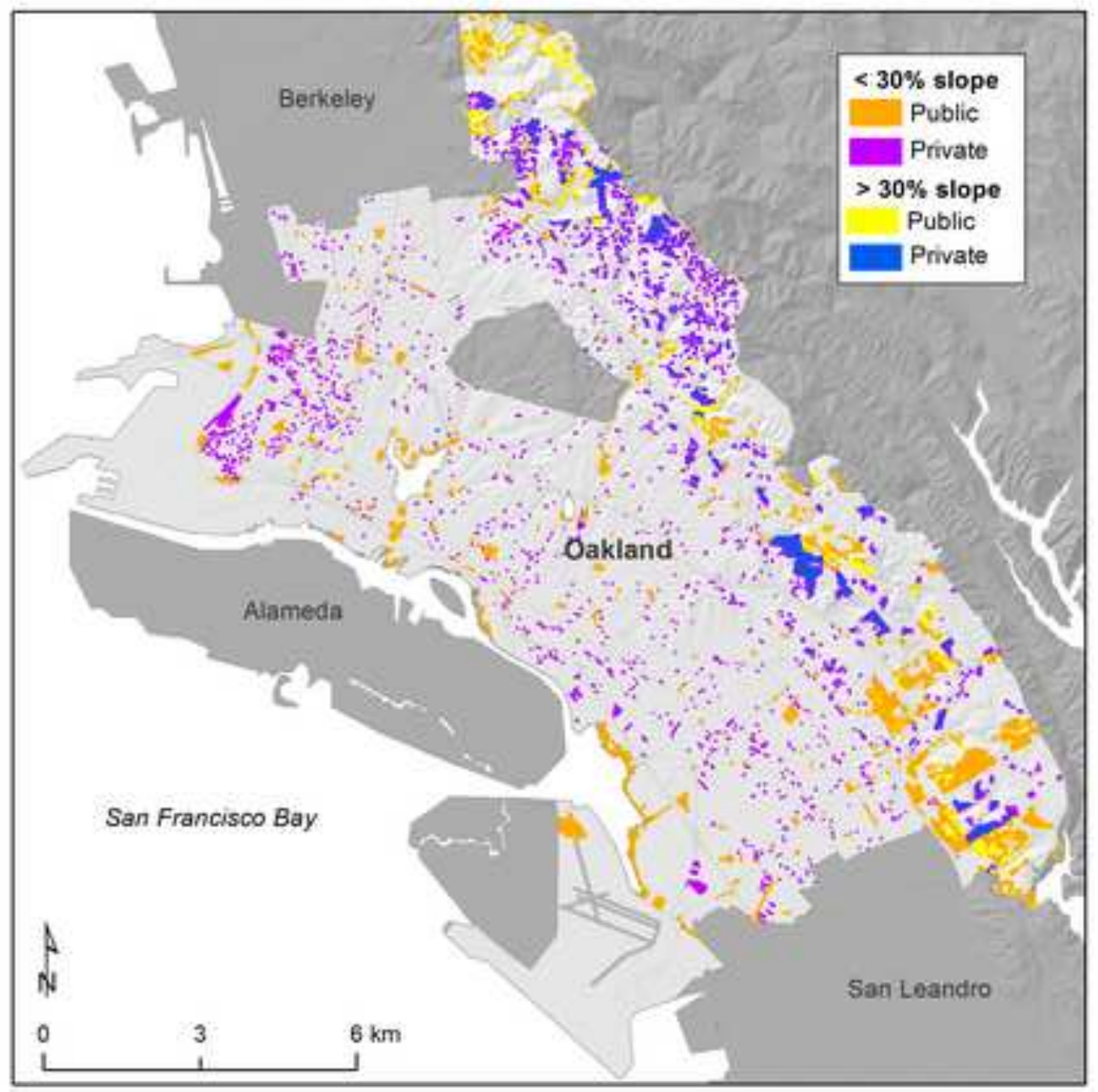




\section{Acknowledgements}

The GIS-based land inventory was partially funded by a mini-grant from the HOPE Collaborative. Ground-truthing for the majority of sites was conducted during a related project funded by a National Science Foundation Doctoral Dissertation Improvement Grant (\#1003598). The project was also made possible by dissertation fellowship funding from the Robert \& Patricia Switzer Foundation, the Institute for the Study of Social Change, and Community Forestry \& Environmental Research Partnerships. We would like to extend our tremendous gratitude to the members of the Community Advisory Committee and the HOPE Collaborative Food Systems Action Team (too numerous to name here) for their timely input and recommendations. Navina Khanna, Alisa Dodge, and Hank Herrera of HOPE, David Ralston of the City of Oakland, Heather Wooten of PHLP, and Barbara Finnin of City Slicker Farms merit special thanks. At UC Berkeley, Kevin Koy and Maggi Kelly in the Geospatial Innovation Facility and Darin Jensen, Mike Jones, and Douglas Allen in the Cartography and GIS Education Lab provided invaluable technical advice, while Nathan Sayre and Jason Corburn offered comments on earlier drafts. Thanks also go out to three anonymous reviewers for their helpful comments on the manuscript. 
Nathan McClintock is an assistant professor in the Nohad A. Toulan School of Urban Studies and Planning at Portland State University where he researches and teaches on urban agriculture and food systems, urban sustainability, and urban political ecology. He earned a PhD in geography from UC Berkeley in 2011 and a MSc in crop science/agroecology from North Carolina State University in 2004, and has worked on sustainable food systems projects in the US, Canada, and throughout the Global South.

Jenny Cooper is completing a MSc in sustainable systems at the School of Natural Resources at the University of Michigan. She received a BA in geography from UC Berkeley in 2008.

Snehee Khandeshi received a BA in geography with a minor in urban studies from UC Berkeley in 2010. 